\title{
Mysticism and Greek Monasticism
}

\author{
By JOHANNES RINNE
}

There is reason to assert that Christian mysticism is as old as Christianity itself. In the Pauline epistles, e.g., there are obvious signs of this fact. The later Christian mysticism has, in a high degree, been inspired by these elements and likewise by various corresponding thoughts in the Johannine writings, which traditionally are interpreted from this angle and which have played a central rôle especially for the Orthodox Church. ${ }^{1}$

In the light of the above-mentioned circumstances, it seems fully natural that there exists, from the very beginning, a clear connection also between mysticism and Christian monasticism. It has been pointed out by certain authors that the rôle of mystical visions is of essential and decisive significance also as regards the development from the stage of the hermits of the deserts to that form of life which, in the proper sense of the word, is characterised as monastic. There is, generally speaking, no possibility to understand correctly the intentions and the thoughts of the great pioneers of monasticism, unless one takes into account the mystically visionary factors. To this end it is necessary, furthermore, to penetrate in an inner, spiritual way, into the holy symbolism of the monastic tradition and into the sacred legends of its history. ${ }^{2}$ In other words, it is necessary to keep constantly in mind the visionary factor and to remember that the pioneers of monastic life, as a rule, are men of which it may be said that they have their conversation in heaven: on the mystical level of vision they converse with the angels as the representatives of the heavenly world and as those organs, by means of which the principles of monastic life are transmitted and given to the men of mystical visions. ${ }^{3}$

The things mentioned above are not merely history. The said way of

1 Cf. C.-M. Edsman, "Mystik", Nordisk Teologisk Uppslagsbok, 2, Lund 1955, cols. I I $44 \mathrm{sq}$.

${ }^{2}$ W. Nigg, Warriors of God, edited and translated from the German by Mary Ilford, I, London I959, pp. 50 sq.

3 Nigg, op.cit., pp. 54 sq. 
thinking, far from belonging only to a remote period in a vanished world, represents a way of reasoning and of experiencing reality, which even to-day can be found to be quite natural among the monks of the ancient orthodox monasteries of Mount Athos, Sinai, Patmos, or in some other centres in the world of the Greek-speaking brotherhoods. ${ }^{1}$ Visions of various types play also nowadays an important rôle for the fathers and brethren of those monasteries, which for centuries have been abodes of mysticism. It would be an enticing task to try to follow the paths of mysticism within the boundaries of the monastic tradition in question. On the other hand this would be a difficult and extensive undertaking, and for several reasons unfeasible in the present connection. Consequently, we shall pay attention only to a couple of names and phenomena, which are representative of the mysticism of the Greekspeaking monastic world, although this is bound to mean, unfortunately, that the total picture becomes incomplete and defective, in some measure, as a considerable amount of important material must be left without attention. Perhaps it should be pointed out, furthermore, that when we refer to the Greek-speaking monastic world, the concept has no political limitation: it pertains to that area or to those monastic communities, which have been or are parts of the Greek language cultural sphere. With a few exceptions, we shall chiefly concentrate our attention upon two objects: first, on St. Gregory of Nyssa and his teachings, and second, on that mysticism which is represented by the monastic tradition of the Holy Mountain of Athos.

It is customary to characterise St. Gregory of Nyssa ( $†$ 394) as the father of Christian mysticism, and whatever one may think of the accuracy and justification of the said expression, there is no doubt about his significance: he truly played a rôle of primary importance both for Christian mysticism in general and particularly for the position of Christian mysticism in the monasteries of the Greek world. In Church history he is known as one of the Three Great Cappadocians, together with his brother Basil the Great and Gregory of Nazianz. His close co-operation with the brother, who is regarded as the father of the Greek monasteries, explains, in part at least, why his ideas became so significant within the sphere of the Greek monastic

1 The author has found many proofs of this through his contacts with some monks in Athos, Sinai and Patmos. 
tradition. ${ }^{1}$ Gregory for his part characterises the name of Basil as great among the holy men. ${ }^{2}$

As regards Gregory of Nyssa, it seems just to say, that he during his whole life was occupied with the problem of beholding God and knowledge of God. It is to be observed that all his thoughts, which are related to this matter, constitute an integral part of his system of thinking as a totality, as it is nowadays admitted even in such circles, where his attitude was earlier often characterised as neoplatonic, in the narrow sense of that term, in which case it was usually forgotten that whatever might be said concerning the shape of his thoughts in certain cases, it was his Christian approach and his profoundly and essentially Christian faith that mattered most decisively, from the point of view of contents. This implies, among other things, that if one wants to speak of neoplatonism in Gregory, one has to bear in mind, in any case, that it is fundamentally conditioned by Christianity, in the light of which it is also to be interpreted. ${ }^{3}$

Gregory refers to two ways of salvation. One is called the way of deeds and activity, while the other one is characterised as the contemplative way, and it is emphasised that one of these is necessary for salvation. ${ }^{4}$ It should quite particularly be noticed that the latter way is not called passive, but contemplative, and, furthermore, that these two ways are not thought of as being on the same level: contemplation-especially contemplative beholding-constitutes the higher form of our knowledge of God and it is not reached by means of the normal methods of thought. This implies, among other things, that there are degrees in the realm of spiritual life and that only the perfect may have true knowledge of God. On the other hand, it must be borne in mind that in so far as the spiritual life pertains to the entire ego, the whole of man, there cannot be any absolute cleft or chasm between the practical and the religious. For the same reason it would be utterly unjust to characterise the higher forms of spiritual life as an expression of passivity, quite particu-

${ }^{1}$ Cf. Edsman, op. cit., col. I I45.

2 Fr. Oehler (editor), Gregor's, Bischoff's von Nyssa Gespräch mit seiner Schwester Makrina über Seele und Auferstehung, I, (Bibliothek der Kirchenväter, I:I), Leipzig I958, p. 2.

${ }^{3}$ Cf. Edsman, op. cit., col. I I 45 .

${ }^{4} \mathrm{P}$. Verghese, "The role of Monasticism and New Askesis for our Time", The Ecumenical Review, XV:3, I963, p. 3 I I. 
larly since it is of decisive significance for the Orthodox tradition that we underline, not only the rôle of the grace of God, but also the rôle of human will and human activity, as regards the position of man before God: without this emphasis we cannot understand correctly the nature of mysticism from the point of view of prayer, spiritual purification, and contemplation. ${ }^{1}$

Gregory rejects expressly the idea that the visible things would constitute the limit for the essence of things and that the perceptions of our senses would be the criterion as regards our knowledge of the universe. ${ }^{2}$ Such an attitude would mean, according to him, that the spiritual organs of man's mind are ignored and left unused or that they are closed for everything and that one cannot study anything non-corporal nor anything that belongs to the realm of thought alone. Here Gregory makes use of a simple but expressive parable: he asserts that a person with the said attitude resembles a man, who has been shut up in a house and lacks every possibility to behold the wonders of the sky, because the walls and the roof hinder him from this. In this connection also the difference between the various forms of knowledge becomes fairly clear, when Gregory remarks that the things perceptible for our senses in the universe are like the walls of the world, which may conceal the things that are spiritually comprehensible or the beholding of knowledge. ${ }^{3}$

Man is like a microcosm which contains the elements by means of which the universe has been formed as an entirety or as a whole. ${ }^{4}$ The soul of man is a created, living being with the faculty of thought. ${ }^{5}$ This opens the way for that contemplation which is independent of the sensual perceptions, based on visible objects.

Every thing and character draws to itself that which is akin to it. Human nature is, in its own manner, akin to the divine and thus it has some traces of its prototype. This implies, among other things, that man's soul is drawn toward the divinity. From this point of view it matters essentially, whether man is weighed down by things material or whether he in an ever higher degree is free from them: in the former case the movement in question is

${ }^{1}$ Cf. K. Boris, "The Orthodox Conception of the Spirituality of the Church in Relation to Daily Life", The Ecumenical Review, XV:3, I963, p. 309.

${ }^{2}$ Cf. Oehler (ed.), op. cit., p. ro.

${ }^{3} \mathrm{Cf}$. ibid., pp. Io and 12.

${ }^{4}$ Cf. ibid., p. 16.

${ }^{5}$ Cf. ibid., p. I8. 
hindered or rendered more difficult, in the latter case it becomes considerably easier. ${ }^{1}$ In the former case the problem may even become very painful for man, but the reason is not that God would want to cause pain: the explanation is that God, who is the source of all true happiness, calls upon everything that has come into existence for His sake, and this may, under certain circumstances, cause or necessitate a process of purification and liberation, which is experienced as something painful, at least to begin with. ${ }^{2}$ In this connection it should be observed, furthermore, that because the evil in man's nature does not exist outside the will, this implies that if man reaches so far, in his process of purification, that the totality of his will is in God, the evil is entirely annihilated, because there is no more any room for it in man. ${ }^{3}$ This purification implies that the soul is made clean from everything earthly, and thus man may, in the said condition, receive God in his heart: beholding God means, in this sense, that man possesses God in his inner being, and this is essentially different from only knowing something about God. This experiencing of God is sometimes characterised as the "night of thinking", since God is incomprehensible, and in this sense it may also be said that Gregory makes a clear distinction between symbolic and negative theology: the former makes statements concerning the attributes of God, while the latter emphasises the incomprehensibility of the essence of God. The purification process of the soul, it may be said, results in the "night of the senses", and this implies a situation, in which the indwelling of God in man is made possible, a state of things that may be experienced as the night of thinking. ${ }^{4}$

As regards the way of man before God, his search for beholding, we may, furthermore, pay attention to a particular idea among the central thoughts of St. Gregory: no attitude of neutrality is possible, in the proper sense of that term. Good and evil are exclusive contrasts, and man is characterised by one of them. If somebody is ruled over by the evil, this implies, eo ipso, that he cannot be controlled by the good. The negative qualities of man are conditioned by the evil, and this means that in so far as man, through the process of purification, is made free from the evil, the good or the positive qualities

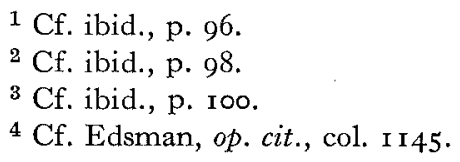


obtain a foothold in him, and the godlikeness is ever more made real and present. ${ }^{1}$ There is no possibility for us to go deeper into this problem, within the frame of the present short paper, but there is reason to point out, in passing, that the said circumstance is one of those factors which make it clear, that there exists a direct connection, or a relation of dependence of a special kind, between the contemplative life and the so-called practical life, a thing which, as a matter of fact, must be considered as entirely natural in view of the emphasis that is put upon man's co-operation with God and upon the rôle of will—as we have remarked previously-although it is of essential significance to remember that this is not the only thing that is underlined, and that this aspect, furthermore, represents something that is of preparatory and contributory character.

In the days of St. Gregory of Nyssa, mysticism had some particularly important representatives among the Egyptian monks, who, in part at least, create even their own expressions of the same basic tradition. The heritage is then carried forward, along different roads and in different ways, and it is thus brought also to the various generations of monks within that monastic world, which then became known as Byzantine. That tradition was well taken care of and even developed. In this respect a particularly central and significant rôle was played by men like John Climacos, Hesychios the Confessor, Nicethas Stethatos, and the so-called hesychasts. ${ }^{2}$ The tradition in question has been especially prominent in the Holy Mountain of Athos, as we have already indicated, in passing, and our next task will be to pay some attention to this matter.

The monastic republic of Athos-the renowned Holy Mountain of the entire Orthodox world-has throughout centuries been one of the most important centres of Orthodox piety. In order to understand this, one should first understand the inner structure of Orthodox religious life and the emphasis which is put upon the connection of Orthodox tradition and Johannine Christianity. Within the mystical world of Athos it has always been underlined, among other things, that the Church, to Her very nature, is an organ, which, here in the world, is the medium of divine, transforming love, but at the same time it has been understood that the mystical tradition of the Desert

${ }^{1}$ Cf. Oehler (ed.), op. cit., pp. 168 and 170.

${ }^{2}$ Cf. Edsman, op. cit., col. I 466 . 
Fathers of Egypt, e.g., is to be kept closely together with this teaching and that it constitutes an essential presupposition for the preservation and the deepening of the atmosphere of the holy: it is necessary for the monks to turn constantly away from the world and toward God, in order that the divine, transforming love may be conveyed to them and through them to the world. ${ }^{1}$ Athos represents in many ways that eastern tradition, where mysticism and conceptual thinking are never basically in conflict in such a sense that they would exclude each other. It is considered that the explanation of this lies in the fact that neither concept nor emotion are decisive for this tradition, but rather the idea as a reality which fills the whole of man. Here we encounter an attitude which constitutes an outstanding contrast to that atmosphere of intellectualism and materialism which so often prevails in our world of to-day. ${ }^{2}$

The mystical tradition of Athos is quite particularly represented by the hesychasts, and for this reason it seems both justifiable and necessary that we chiefly restrict ourselves to this movement or phenomenon and refrain from a more comprehensive treatment of the monastic mysticism of the Holy Mountain.

The term hesychasm derives its origin from the Greek word hesychiapeace, calm, quietness, tranquillity. Thus the hesychast, in other words, is a person who wishes to dedicate himself, in peace, to meditation and private prayer, in order to gain peace in an ever higher degree. The necessity of quiet and silence from the point of view of spiritual development in monastic life was, by the way, strongly underlined already by Basil the Great, too. He saw in these things the basic presuppositions for everything else in connection with the spiritual progress of the monk. ${ }^{3}$ The hesychasts of Athos have the same goal, whose value Basil so often emphasised: attaining peace of soul by means of mystical experience.

The great name of hesychasm is Gregory of Palama ( $\uparrow$ r 359 ). He is often characterised as the father of hesychastic piety, but this is, of course, misleading and even incorrect: he is rather the most prominent among the known champions of hesychasm, for the movement as such, i.e. search for the peace

\footnotetext{
${ }^{1}$ Cf. K. Eller, Der Heilige Berg Athos, I, München I954, p. I3.

${ }^{2}$ Cf. Eller. op. cit., p. 14.

${ }^{3}$ Cf. Nigg, op. cit., p. 73 .
} 
of soul and spiritual tranquillity, is of the same age as monasticism or strictly speaking considerably older. When Gregory of Palama appeared as a representative and advocate of the said tradition, there were great differences of opinion, to begin with, one of the reasons being that it was thought that his emphasis upon the rôle of contemplation implied a danger to the principle and practice of fellowship, and there were those, who spoke scornfully of the hesychasts as men who meditated over the navel, while the hesychasts, as a matter of fact, tried to concentrate their entire thinking activity and attention upon prayer and directed, as it were, their eyes inwards. It is rightly asserted that only the uninformed may reject the hesychasts in this way, for these mystics are great masters of prayer, who, by means of their contemplative concentration, reach a stage which for them may include a vision of the Uncreated Light, which shone around the Transfigured Christ. ${ }^{1}$ If one is privileged to discuss these matters with contemporary monks in Athos, one may hear detailed descriptions concerning various kinds of visions of light. In those contexts it becomes clear that there are visions of different quality and value, some of them positive, some negative, and that these latter, which have their particular characteristics, are the work of the evil powers in their fight against those men, who wish to come into an ever closer fellowship with the divine. ${ }^{2}$

The hesychasts practise in a high degree the so-called "prayer of Jesus" or the "prayer of heart", which in one of its most authentic forms reads: Lord Jesus Christ, Son of God, have mercy upon me. ${ }^{3}$ To begin with, man prays with his lips and he must concentrate his thoughts upon what he is saying, in order to understand it, but if he endures and perseveres in prayer and really prays unceasingly, his intellect and heart are united in this prayer, which fills his entire being and consciousness: then it is no more necessary for him to exert the strength of his thought in order to express the words of

${ }^{1}$ Cf. Nigg, op. cit., p. 85, and T. Ware, The Orthodox Church, I, Bungay I963, p. 75 .

2 The author has had such discussions with some Athonian monks. Red light is, generally speaking, seen as a negative value, while white light implies a positive experience.

${ }^{3}$ Cf. A Monk of the Eastern Church, The Prayer of Fesus (translated from the fourth French edition by a monk of the Western Church), I, Tournai I967, p. 97. 
the prayer, for the prayer of Jesus has become one with his life and goes on without ceasing. ${ }^{1}$

Century after century the mystical hesychastic tradition lived on in the Holy Mountain and resulted in an ever richer spiritual life, especially during the latter half of the I8th century, at which time a monk, called Nicodemus of the Holy Mountain ( $\uparrow$ ×809), compiled, with the assistance of a Greek bishop, a comprehensive anthology, which contains writings, full of mystical piety, from a period which covers more than a thousand years. The anthology in question is called the Philocalia and it was printed in Venice in I782. A very essential and considerable part of the contents deals, in good hesychastic spirit, with the practice and the theory of prayer, and particularly with the prayer of Jesus. The Philocalia may justly be characterised as one of the most influential publications within the Orthodox world, from the point of view of many countries and language areas, but it is not our task to discuss this aspect of the matter in the present context. ${ }^{2}$ We shall, instead, finally get acquainted with some of the thoughts which are included in the Philocalia, this flower of the monastic mysticism of Athos.

There are, in the Philocalia, several concrete and practical directions and a great deal of valuable advice for the spiritual life of men in general, but the most detailed teachings deal with prayer. Here it is spoken of different degrees of purification, exercises for remembering God, stages of prayer, concentration upon God, spiritual soberness, firmness of mind, different ways of prayer, right ways of breathing at prayer, silence, use of psalms etc. ${ }^{3}$

It lies in the nature of the matter that Gregory of Palama left a rich spiritual heritage behind himself and that this is well represented in the Philocalia. At the end of the present paper, we shall still make some references to the material in question.

Gregory of Palama emphasises that there is nothing evil in the fact that the spirit dwells in the body: the evil has its abode in the law of sin, which is

\footnotetext{
${ }^{1}$ Cf. ibid., pp. 99 sqq., and G. E. H. Palmer (editor and translator), Early Fathers from the Philokalia, I, London 1954, p. 412 (From the Life of St. Gregory Palamas).

${ }^{2}$ Cf. Ware, op. cit., p. I Io.

${ }^{3}$ Cf. Palmer (editor and translator), op. cit., pp. I 83 sqq. (Isaac of Syria), and E. Kadlenbovsky and G. E. Palmer (ed. and transl.), Writings from the Philokalia on the Prayer of the Heart, 4, London I952, pp. 21 sqq. (Nicephorus the Solitary), pp. 97 sqq. (Simeon the New Theologian), and pp. 74 sqq. (Gregory of Sinai).
} 
struggling against the law of the spirit and which rules over our limbs. For this very reason it is for us to fight against the law of sin and to dispel it from our bodies, in order that the spirit may take its place. We try to ennoble and elevate our spirit by means of withdrawing from everything that prevents us from asceriding toward God, and this is called spiritual soberness. ${ }^{1}$

If anyone wishes to fight against sin, attain virtue and obtain its reward and spiritual understanding, he must guide his spirit into his innermost self. If we give freedom to the spirit to dwell outside of the body in order that it may there look for what it wants to ponder upon, we favour the mistakes and errors of the ancient Greeks. Such a spirit, which is directed inward, does not go astray: it comes into consciousness and ascends along the right and sure path to God. ${ }^{2}$

As regards the entire mystical hesychastic tradition, Gregory of Palama points out, that several ancient authorities exhort us to persist in this heritage and to hold on to it. He adds, however, that the "present teachers"- those of his days 600 years ago-despise and disdain this concentration upon God and try to belittle and even to annihilate the doctrine in question. He underlines, for his own part, that there is no reason for us to disdain the ancient teachers and their experiences, which they have received by grace and through prayer. Those who speak against the way of mysticism for the monks, they act out of pride and arrogance, stresses the great hesychast. ${ }^{3}$ In him speaks the ancient tradition of monastic mysticism, a tradition that was old already before he himself was born and that lives still to-day, in many parts of the Greek-speaking monastic world and outside of it, in the various lands of Orthodoxy.

\footnotetext{
${ }^{1}$ Cf. Palmer, op. cit., p. $40 \mathrm{I}$.

${ }^{2}$ Cf. ibid., pp. 403 sqq.

${ }^{3}$ Cf. ibid., pp. 408 sq.
} 